\title{
Governing by targets: reductio ad unum and evolution of the two-degree climate target
}

\author{
Piero Morseletto $^{1} \cdot$ Frank Biermann $^{2} \cdot$ Philipp Pattberg $^{1}$
}

Accepted: 28 September 2016/Published online: 6 October 2016

(C) The Author(s) 2016. This article is published with open access at Springerlink.com

\begin{abstract}
Targets are widely employed in environmental governance. In this paper, we investigate the construction of the $2{ }^{\circ} \mathrm{C}$ climate target, one of the best known targets in global environmental governance. Our paper examines this target through a historical reconstruction that identifies four different phases: framing, consolidation and diffusion, adoption, and disembeddedness. Our analysis shows that, initially, the target was science-driven and predominantly EU-based; it then became progressively accepted at the international level, despite a lack of broader debate among governments on the policy implications and required measures for implementation. Once the $2{ }^{\circ} \mathrm{C}$ target was endorsed at the level of the United Nations, the nature of the target changed from being policy-prescriptive to being largely symbolic. In this phase, the target became a disembedded object in global governance not linked to a shared agenda nor to coordinated and mutually binding mitigation efforts. The 2015 Paris Agreement marks the last stage in this development and may have further solidified the target as a disembedded object. In the final part of the paper, we suggest ways to overcome the current situation and to develop the $2{ }^{\circ} \mathrm{C}$ target into a fully fledged global environmental governance target.
\end{abstract}

Keywords $2{ }^{\circ} \mathrm{C}$ target . Global environmental governance - Climate governance International relations and politics · Governing by targets

\section{Introduction}

Targets have become an increasingly important tool of environmental governance, from national environmental targets to targets within broader global goals such as the Sustainable Development Goals (Kanie and Biermann 2017; Bergh and Couturier 2013). In

Piero Morseletto

piero.morseletto@vu.nl

1 Institute for Environmental Studies (IVM), Faculty of Earth and Life Sciences, VU University Amsterdam, 1081 HV Amsterdam, The Netherlands

2 Copernicus Institute of Sustainable Development, Faculty of Geosciences, Utrecht University, 3508 TC Utrecht, The Netherlands 
governing by targets, we refer to the tendency to rely on these instruments for framing responses to environmental problems. Such a theoretical perspective suggests the importance of investigating how targets are formed, stipulated and employed. This paper analyses the $2{ }^{\circ} \mathrm{C}$ target-the envisaged maximum mean temperature increase above preindustrial levels - that governments agreed upon to be the target of the UN Framework Convention on Climate Change. The $2{ }^{\circ} \mathrm{C}$ target aims at pulling together countries' efforts to avoid the dangerous impacts of climate change. As such, it arguably is one of the most prominent targets in global environmental governance. However, the choice of a single figure represents a reductio ad unum, that is, bringing multiple issues down to a single element. Our analysis investigates the process that led to the $2{ }^{\circ} \mathrm{C}$ figure and addresses three main research questions: (1) What factors shaped the emergence and development of the $2{ }^{\circ} \mathrm{C}$ target over time? (2) What functions does the target perform in the political arena? (3) In how far does the target fulfil the scope for which it was created?

To answer these questions, we identify and examine different phases in the evolution of the target. This includes considering the actors, approaches and institutional contexts that marked the progression of the target. Moreover, the phase-approach makes it easier to confront the target with key concepts from the fields of environmental governance as well as science and technology studies (notably on the interplay between scientists and policymakers, the interests of political actors and on strategic approaches in negotiations).

In the scholarly literature, environmental governance targets have been addressed by a variety of disciplinary approaches in the context of regime theory (Young and Levy 1999; Mitchell et al. 2006; Haas et al. 1993), scientific assessments (Cash 2000; Watson 2005), environmental diplomacy (Barrett 2003; Grubb 1990) and international policy-making (Dietrich 1995). These studies suggest that governing by targets is a key element of the structure and dynamics of environmental governance. Our paper contributes further to the understanding of the role and construction of environmental targets by offering a detailed historical reconstruction of the emergence of the $2{ }^{\circ} \mathrm{C}$ target from a governance perspective. Our work draws on extensive document analysis of reports, scientific literature, official documents, as well as on a series of in-depth interviews ${ }^{1}$ with individuals who were involved with the formulation of the $2{ }^{\circ} \mathrm{C}$ target at various decision-making levels and in different roles. ${ }^{2}$

\footnotetext{
${ }^{1}$ The analysed documents were collected from libraries, data banks and online platforms. Some documents were requested from the responsible organisations, consulted in situ or provided by the authors. For data collection, 10 in-depth interviews were arranged. The interview format was based on a protocol structured around 12 main questions, with multiple sub-questions, all identical for each interviewee: Marcel Berk (Netherlands Ministry of Infrastructure and the Environment), Kornelis Blok (Ecofys; Utrecht University), Michel Den Elzen (PBL—The Netherlands Environmental Assessment Agency), Niklas Höhne (Ecofys), Jip Lenstra (ECN-Netherlands Energy Research Centre), Henk Merkus (Netherlands Ministry of Infrastructure and the Environment), Leo Mayer (PBL-The Netherlands Environmental Assessment Agency), Bert Metz (European Climate Foundation), Robert Swart (Wageningen University and Research Centre) and Pier Vellinga (VU University Amsterdam and Wageningen University and Research Centre). All interviews except one were conducted in August 2012. Eight interviews were conducted in direct meetings, and two over the telephone. The interview format was based on an interview protocol structured around 12 main questions, with multiple sub-questions, all identical for each interviewee. All interviews were recorded with permission of the interviewees and transcribed verbatim. Anonymity of interview content was agreed upon by each respondent to protect confidentiality, and quotations are reproduced with permission of the interviewee.

${ }^{2}$ Most interviewers are Dutch or worked for Dutch institutions. The interviews were intended to be instrumental to get insights into specific historical events and on contextual conditions in which these occurred. The diversity of sources of information—interviews, secondary and primary data—for the current study allows for triangulation to increase the reliability of findings.
} 
The paper is organised as follows. Section 2 introduces the concept of (environmental) targets, while Sect. 3 examines the evolution of the $2{ }^{\circ} \mathrm{C}$ target over different periods. Subsequently, we discuss the implications of the 2015 Paris Agreement (Sect. 4) and suggest ways to further operationalise the target and make it a fully fledged global environmental governance target (Sect. 5). The final section summarises the key findings.

\section{Targets, their mechanics and boundary objects}

Before we engage in a reconstruction of the $2{ }^{\circ} \mathrm{C}$ target in climate policy, we first discuss in more detail the general concept of targets. Targets can be defined as a meaningful reference value that expresses a desired operational policy outcome in a synthetic (often numerical) manner. Targets differ from goals and indicators. Goals are non-operational overarching objectives that usually require targets in order to achieve them. Indicators are parameters signalling a state or a condition and they are generally used to measure targets. Measurability is indeed a powerful and attractive attribute of targets: it increases the sense of governability, allows monitoring of advancements or deviations and favours the application of economic tools and techniques (Asdal 2008; Miller 2005).

Setting targets entails several steps: identification, discussion, negotiation, agreement, implementation, evaluation and-if required-modification or revision. This process can involve numerous stakeholders at multiple levels of governance, from local to international (Mitchell 2003; Jänicke and Jörgens 2006; Hák et al. 2007; Lester and Neuhoff 2009). Targets rely mainly on scientific knowledge, but science and policy interact in their construction and stipulation, illustrating the dynamic interactions among knowledge-producers, knowledge-users and intermediaries in decision-making (Sarewitz and Pielke 2007; Pierson 2000).

In the definition of targets, different interpretations can arise regarding the metrics to choose, the data classification and standardisation procedures or the quantitative/qualitative value of a target (Bowker and Star 1996, 1999; Turnhout et al. 2007; Davis et al. 2012). Discussions also occur on the suitability and feasibility of a target, as well as on the ways to produce substantive policy responses to reach the desired outcomes. The reference value that emerges is a synthesis of scientific contents, strategic views and problem-solving attitudes and it is proportional to the level of ambition. Moreover, selected targets tend to be simple, because simplification may facilitate managing complex systems (Turnhout et al. 2007). Moreover, simpler targets are easier to use, understand and communicate.

A target is therefore a hybrid. It is neither purely scientific nor political; rather, it is a nested concept that helps to make things work together (Bowker and Star 1996). This includes conflicting interests, worldviews, expectations, commitments, societal needs, scientific understandings, political intentions or organisational programmes. Accordingly, a target is a unifying element, which works as boundary object, i.e. a set of arrangements that allow different actors to cooperate on a basic common understanding while keeping the diversity of their views (Star 2010; Star and Griesemer 1989). Still, a target is usually presented as cohesive, objective and scientifically proven (Porter 1995; Asdal 2008). These aspects strengthen its normative façade: a target affirms what is legitimate to reach, indicates the direction to be taken and provides the common language to translate priorities and programmes into a policy outcome.

The concept of a boundary object is then useful to navigate the construction and evolution of a target. It offers an analytical angle to look at all the elements coalescing into 
a target: concerns and hopes, problems and solutions, scientific knowledge and political views, promises and results.

\section{Climate change and the $2^{\circ} \mathrm{C}$ target}

The origins of the $2{ }^{\circ} \mathrm{C}$ target in climate governance go back almost half a century. This target was first mentioned, to our knowledge, in a paper by Manabe and Wetherald (1967), who estimated a temperature response to doubling carbon dioxide concentrations by approximately $2{ }^{\circ} \mathrm{C}$ (Randalls 2010). Since then, the $2{ }^{\circ} \mathrm{C}$ figure has been discussed in various studies, including in relation to climate governance (Bodansky 2010, 2011; Dimitrov 2010), the science-policy nexus and the diffusion mechanism in climate diplomacy (Gippner 2014), its implications and policy options (Geden 2010; van Vliet et al. 2012; Höhne and den Elzen 2013) and conceptual or critical aspects of the target (Tol 2007; Shaw 2010; Boykoff 2011; Lenton 2011b; Jordan et al. 2013). Other authors followed the chronology of events for investigating the multifaceted characteristics of the $2{ }^{\circ} \mathrm{C}$ target: to consider different interpretations of the target (Jaeger and Jaeger 2010; Knopf et al. 2012), to explore its strengths and weaknesses (Randalls 2010) and to examine its role as an intertwined element of science and policy (Oppenheimer and Petsonk 2005; Cointe et al. 2011). In the following sections, we discuss the development of the $2{ }^{\circ} \mathrm{C}$ climate target over four distinct phases: framing, consolidation and diffusion, adoption and disembeddedness.

\subsection{Framing (1988-1996)}

The $2{ }^{\circ} \mathrm{C}$ climate target had rarely appeared in scientific literature before the late $1980 \mathrm{~s}$ and was used as a heuristic rather than as normative policy-guidance (Randalls 2010). For this reason, we consider the political history of the $2{ }^{\circ} \mathrm{C}$ target as starting in 1988 with the World Meteorological Organization report Developing Policies for Responding to Climatic Change (WMO 1988). The report summarised the findings of two meetings in 1987 (in Villach, Austria, and Bellagio, Italy) of the Advisory Group on Greenhouse Gases, a small advisory body of highly reputed international experts that was created by the World Meteorological Organization, the International Council for Science and the United Nations Environment Programme. This report was intended to offer recommendations for the development of a climate convention by examining the underlying science and its implications for policy (Torrance 2006). In Bellagio, the $2{ }^{\circ} \mathrm{C}$ target emerged together with a target of a $0.1{ }^{\circ} \mathrm{C}$ temperature increase per decade as the maximum acceptable limit. According to anecdotal evidence, these concrete targets were first debated at a dinner conversation and then formally discussed the day after (Tol 2007; Randalls 2010).

Following these initial discussions, the scientific rationale for the target was strengthened. In July 1988, the Advisory Group on Greenhouse Gases established three working groups, all coordinated by the Stockholm Environment Institute. The report of the working group on "Targets and Indicators of Climate Change" - chaired by scientists Pier Vellinga and Peter Gleick-considered a $0.1{ }^{\circ} \mathrm{C}$ increase per decade and a $1^{\circ}$ or $2{ }^{\circ} \mathrm{C}$ increase as temperature targets, reflecting lower or higher risks of severe damage to ecosystems and nonlinear responses (Rijsberman and Swart 1990). Later on, the $0.1{ }^{\circ} \mathrm{C}$ target faded away. One reason for this is that decadal scales have greater natural variability, which makes such a target less useful in practice (Tol 2007). 
Around this time, the debate on quantitative maximum targets for global warming entered the political arena. Oppenheimer and Petsonk (2005), for example, underline the interest of the Netherlands in informing policymakers about the impact of climate change. The Netherlands was well placed for being influential in this framing phase of the target. It had wide-ranging climate change research together with dedicated political institutions (van Eijndhoven et al. 2001; Rotmans 1990; Pettenger 2007).

In 1989, the Dutch government assigned Pier Vellinga to organise the Noordwijk Ministerial Conference, which was eventually attended by 67 ministers of both developed and developing countries. This important political venue proved to be relevant for setting fundamental principles such as the notion of climate change as a common concern of humankind (Biermann 1997) and - following a Dutch proposal-the concept of tolerable limits of climate change. However, the conference was unable to reach an agreement on temperature limits. A step in this direction was possible only 1 year later with the 1990 Second World Climate Conference, when the Dutch and Austrian delegations were decisive in supporting the idea of a long-term objective (Oppenheimer and Petsonk 2005).

A further step was the publication in the journal Climatic Change of the editorial entitled "The Greenhouse Marathon: A Proposal for a Global Strategy" by Vellinga and Swart in 1991 . Here the $2{ }^{\circ} \mathrm{C}$ figure first appeared in a climate change context as a clear-cut threshold (Cointe et al. 2011) and as a "means of normatively framing a target-based approach to global climate policy" (Mahony and Hulme 2012: 78). The article gained political significance as it proposed an advanced visual explanation based on a traffic light representation that supported the necessity of the $2{ }^{\circ} \mathrm{C}$ increase as a temperature limit. The proposal stated, "In absolute terms we are in the red zone when the increase in global mean temperature is $2^{\circ}$ or more above preindustrial levels" (Vellinga and Swart 1991: VII). The $2{ }^{\circ} \mathrm{C}$ target was then authoritatively framed, but it needed to be further discussed in the political arena.

In 1992, article 2 of the climate convention stipulated as the "ultimate objective" the "stabilisation of greenhouse gas concentrations in the atmosphere at a level that would prevent dangerous anthropogenic interference with the climate system" (UNFCCC 1992). The treaty did not, however, provide a numeric value. It is important to record that this text combined elements of the statements of both the Noordwijk and the Second World Climate Conference (Oppenheimer and Petsonk 2005). Moreover, the long-term target approach was adopted from the similar approaches in European governance of long-range transboundary air pollution and water quality (Swart and Vellinga 1994).

Shortly before the first conference of the parties in Berlin in 1995, the German Advisory Council on Global Change proposed an innovative approach to climate change mitigation based on temperature ranges and emission quotas. The so-called tolerable windows approach recommended limiting a global mean temperature rise to less than $2{ }^{\circ} \mathrm{C}$ (WBGU 1995). Jaeger and Jaeger (2010) underline the importance of this German institute, especially of its chairman Hans Joachim Schellnhuber, in convincing Angela Merkel-then Germany's Minister of the Environment-about the relevance of the $2{ }^{\circ} \mathrm{C}$ target.

During Merkel's term as environment minister (1994-1998), the Council of the European Union (EU) stated that "given the serious risk of such an increase [in temperature] ... the Council believes that global average temperatures should not exceed 2 degrees above pre-industrial level" (Council of the European Union 1996: item no 6 of Community Strategy on Climate Change). The limit was derived from the evidence available at the time, mostly from impact studies that were considered in the 1995 Intergovernmental Panel on Climate Change's Second Assessment Report (Metz 2010). This political act can be considered the last and most relevant step of the framing phase of the $2{ }^{\circ} \mathrm{C}$ target. 
Regarding this early stage of the $2{ }^{\circ} \mathrm{C}$ target's political development, some important points should be emphasised. First, some scholars see the emergence of the target as being biased by value judgements of scientists who defined what limits they considered dangerous (Metz 2010). The $2{ }^{\circ} \mathrm{C}$ value falls into the consensus estimate of $1.5-4.5^{\circ} \mathrm{C}$ with regard to climate sensitivity (van der Sluijs et al. 1998). Among the scientific community, this concept proved to be complex because of the estimated variables and the related uncertainties (Shaw 2010). Those include the equilibrium global mean surface temperature change following a doubling of the atmospheric carbon dioxide concentration relative to the pre-industrial period (van der Sluijs et al. 1998). A target like the $2{ }^{\circ} \mathrm{C}$ increase was a suitable simplification for non-specialists as a much handier and more easily understandable concept. However, this scientific simplification was never proposed in absolute terms for policy. The related uncertainty was constantly highlighted. Equally, the role of policymakers in deciding what is dangerous for society was always recognised. For instance, the 1988 Targets and Indicators working group stated that the choice of target "will be a product of the political process of negotiations" (Rijsberman and Swart 1990: X). Still, in climate science "some form of value judgement is inevitable" (Gupta and Van Asselt, 2006: 84), as experts' activity is "a hybrid activity that combines elements of scientific evidence and reasoning with large doses of social and political judgement" (Jasanoff 1990: 229).

Second, it is important to note that, at the beginning, only a few activist and pioneering countries, notably the Netherlands and Germany, promoted the target in both the scientific and political domains. Their action helped to spread the idea of the target while giving it stronger political roots (Jordan and Huitema 2014). The Netherlands made scientists and experts available for the definition of a target, together with crucial support by environment ministers (Interviewee 6; Interviewee 7). In any case, climate change was a theme of special political relevance for the Dutch population familiar with environmental risk (Pettenger 2007). Germany embraced the scientific and political process towards the $2{ }^{\circ} \mathrm{C}$ increase slightly later (Interviewee 6; Interviewee 8), then it flexed its political muscles in the process by including the participation of their top politicians and scientists. In Germany, social awareness of climate change was strong. It was home to a robust environmental movement, political parties which included environmental matters in their programmes, and influential environmental non-governmental organisations (CavenderBares et al. 2001). Moreover, the organisation of the first conference of parties to the climate convention, which took place in Berlin, underpinned the leadership role of Germany (Yamin 2000).

Third, these pioneering countries also marked the prominence of Europe in giving stability and political substance to the target. This prominence can also be understood in comparison with the USA. While the US government was formally in favour of stabilising greenhouse gas concentrations (Oppenheimer and Petsonk 2005), it opposed accepting any clear target at that time (Randalls 2010). Instead, Randalls (2010) explains that the USA favoured the rise of IPCC as a means to prevent the Advisory Group on Greenhouse Gases, which was perceived as being too politically oriented, from advancing an agenda ahead of scientific and governmental review of climate change science. Consequently, a first instability at the political level emerged, with two powerful actors in the climate process having different positions, with Europe strongly believing in the target approach and the US remaining reluctant to engage with it.

In the political domain, there was another notable instability, i.e. the lack of debate among decision-makers about the implications of the target and about the most effective means of implementation. From interviews and document analysis, it can be inferred that 
the $2{ }^{\circ} \mathrm{C}$ target materialised in Europe as an easy and useful guidance for policy and a way for policymakers to construct climate change as a problem for the future (Shaw 2010). This explains why EU policymakers accepted the target in such a smooth manner. The absence of intense debate about the meaning and implications characterised the target as a particularly consensual boundary object, in which policymakers showed (at least tacit) trust in the underlying scientific content. European decision-makers at that time did not request further scientific scrutiny and did not challenge the idea of a limit (Interviewee 2; Interviewee 3; Interviewee 8). The ease in reaching a political decision was related to both the quality of the documentation presented and the clarity of the proposal. This is an example where trust is a key component in the science-policy relationship (Whyte and Crease 2010; Hunt and Shackley 1999). In environmental risk communication, trust and credibility are determined by factors like the perceived competence and objectivity of the source (Peters et al. 1997; Renn and Levine 1991). Trust might be also attributed to opportunism of policymakers in placing responsibility for action onto the scientists (Grundmann 2006) or on misinterpretation by policymakers of the meaning and implications of the $2{ }^{\circ} \mathrm{C}$ target. In this regard, trust can be considered as intertwined with a pragmatic calculation by policymakers in balancing what looked reasonable and politically/economically feasible, but also responding to societal concerns and requests of environmental movements (Randalls 2010, 2011). The target offered a unifying element for policy engagement to lock-in multiple actors into a long-term commitment (Boykoff et al. 2010). Yet, the target was simple, appealing and based on allegedly best available science. These elements eased its consensual acceptance. Decision-makers therefore accepted the level of risk presented by scientists, translating it into the level of risk that a society would take, but without a thorough inquiry into its societal implications.

In sum, this first framing phase showed a $2{ }^{\circ} \mathrm{C}$ target that was science-driven (quantified as a possible target for climate change), EU-led (mainly prompted by north-western European countries and their policy-making experiences, with only marginal resistance from the USA and limited involvement of developing countries), trust-based (easily accepted without further investigation by policymakers), but lacking debate and contestation (with a substantial absence of a thorough debate by decision-makers about political and practical implications of the target). Nonetheless, different actors-including scientists, advisory bodies, policymakers, as well as national and international civil servantswere involved in the process. Many events took place to mark the institutionalisation of the $2{ }^{\circ} \mathrm{C}$ target science-policy nexus, with policymakers recognising and accepting the scientific content of the target and making it a guiding objective for policy (Underdal 2000).

\subsection{Consolidation and diffusion (1997-2009)}

The 1997-2009 period led to the further consolidation and diffusion of the $2{ }^{\circ} \mathrm{C}$ target. In 1997, the Kyoto Protocol was adopted, including, for the first time, quantitative emissionreduction targets for industrialised countries. Besides the effort of the EU to establish a long-term temperature target (Metz 2010), Kyoto did not prompt any evolution in terms of further political decisions. After Kyoto, the $2{ }^{\circ} \mathrm{C}$ target nearly disappeared from mainstream political debate. Ultimately, the Kyoto Protocol, a cornerstone of the climate change regime, required great adjustment efforts to make it possible for it to enter into force in 2005 (Oberthür and Ott 2010).

In 2005, however, the $2{ }^{\circ} \mathrm{C}$ target strongly came back into political discourse through a dense sequence of events. In January 2005, a report by the International Climate Change Taskforce-an alliance of the Institute for Public Policy Research in the UK, the Center for 
American Progress in the USA and the Australia Institute-recommended "a long-term objective of preventing average global surface temperature from rising by more than $2{ }^{\circ} \mathrm{C}$ " (ICCT 2005: 3). In February 2005, the Exeter Conference-a preparation event for the G8 summit in the UK-explored temperature thresholds that could trigger irreversible catastrophic events. These scientific findings were collected in a book (Schellnhuber et al. 2006), in which the $2{ }^{\circ} \mathrm{C}$ target was analysed, alongside other limits, and evaluated in terms of emissions pathways.

Within a few days after the Exeter Conference, a European Commission communication stated that "scientific evidence indicates that even meeting the $2{ }^{\circ} \mathrm{C}$ target will require significant preventive and remedial adaptation efforts around the globe" (Commission of the European Communities 2005: 7). In March, the Presidency Conclusions of the Council of the European Union stated: "The European Council [...] confirmed that, with a view to achieving the ultimate objective of the UNFCCC, the global annual mean surface temperature increase should not exceed $2{ }^{\circ} \mathrm{C}$ above pre-industrial levels" (Council of the European Union 2005: 15). In mid-2005, the governments of the Group of Eight (G8) convened in Gleneagles (UK), with climate change being a key topic on the agenda. Governments held the first G8 Climate Change Roundtable, which was constituted in January at the World Economic Forum in Davos. In 2008, the $2{ }^{\circ} \mathrm{C}$ target appeared in the Breaking the Climate Deadlock Initiative, led by former British Prime Minister Tony Blair and presented at the G8 summit held in Japan in 2008 (Climate Group 2008).

Before the conference of the parties to the climate convention in 2009, further relevant events occurred. First, there was the publication of a report by the German Advisory Council (WBGU 2009) which provided a better scientific foundation for the target. This study proposed a new budget approach — based on the calculated budget of carbon dioxide emissions still available worldwide-for countries' commitments to global/national decarbonisation trajectories necessary to hold the $2{ }^{\circ} \mathrm{C}$ line (Schellnhuber 2010).

Second, the declarations in 2009 by the G8 and by the Major Economies Forum on Energy and Climate (a dialogue forum of 17 large economies that brought together the Group of Eight with Australia, Brazil, China, India, Indonesia, Korea, Mexico, Russia and South Africa) recognised the scientific view that global temperatures should not to exceed a $2{ }^{\circ} \mathrm{C}$ increase (G8 2009; MEF 2009). These declarations show how the target found increasing international support beyond Europe, especially among major developing countries.

This sequence of events in the 2005-2009 period underlines the increasing global acceptance of the target and allows for some reflections on its political development. First, Europe remained the main force behind the political consolidation of the target, creating a strong linkage among international actors, while giving impulse to the target's acceptance. European countries organised the major international rallies of this phase and EU political action remained visible in terms of declarations and outputs. The $2{ }^{\circ} \mathrm{C}$ target was an already established strategic objective in the EU, which tried to promote the diffusion of the target internationally (Jordan and Huitema 2014; Finnemore and Sikkink 1998).

Second, the target proved to be stable in the international scene. It kept together a variety of actors, while maintaining its significance and force as a proposal. In these terms, the target served as an anchoring device (van der Sluijs et al. 1998), a highly stable boundary object between science and policy, acting as the scientific basis for the political debate. The political events that marked this phase created a path-dependency (Pierson 2000) that consolidated the temperature limit internationally. Here path-dependency was triggered by a cascade of events and outcomes that progressively endorsed the globalisation of the $2{ }^{\circ} \mathrm{C}$ target with consequent worldwide reverberation (see Boykoff 
2011; Shaw 2013; Cointe et al. 2011). The $2{ }^{\circ} \mathrm{C}$ target was able to catalyse interest and broader consent of decision-makers by being easy, broadly appealing and memorisable. The target continued to be appealing as in the framing phase. Through policy, the $2{ }^{\circ} \mathrm{C}$ target was acknowledged as being clear and easily conveyable to the public, but also as "the vaguest and the least directly binding" target (Cointe et al. 2011: 1).

Importantly, the consolidation and diffusion phase occurred under the impulse of political leaders. At the same time, it received increasing consideration by non-governmental organisations and growing attention by public opinion (Shaw 2010; Death 2011). Political leaders saw the necessity in having a target vague enough to avoid the perils of policy implications. Nonetheless, the support of political leaders gave further notoriety and legitimacy to the target.

Consolidation and diffusion ensued through what we term as eventification. This is the organisation of prestigious meetings that provided a spotlight on the target. Through statements and announcements, these events created deepened path-dependency for the future of the target. Yet, the lack of a thorough debate among policymakers on the political and practical implications of $2{ }^{\circ} \mathrm{C}$ target still persisted in this phase, although the 2005-2009 period was characterised by an intense consensus-seeking and consensusmaking activity and the alignment of a few top decision-makers.

The $2{ }^{\circ} \mathrm{C}$ target was then accepted and approved in different contexts, including the most relevant economic forums. However, approval and consensus remained at the surface and the $2{ }^{\circ} \mathrm{C}$ continued to be regarded as a prescription by science which society had to follow, but without considering how. Even if one accepts this explanation, it is difficult to understand the limited reaction of policymakers and the lack of discussion about concrete proposals. It can be argued that in that period, because of events like the non-ratification of the Kyoto Protocol by the United States Senate, the main actors supporting the $2{ }^{\circ} \mathrm{C}$ target focused more on building the largest consensus around the target, than on avoiding discord.

In sum, the 1997-2009 period marked the consolidation and diffusion of the $2{ }^{\circ} \mathrm{C}$ target, with Europe remaining at the forefront but now accompanied by the endorsement of other relevant states. Some inconsistencies persisted in this phase and policymakers still avoided engaging in a debate on the implications of the targets with regard to possible actions for its implementation. Nonetheless, the idea that the target was ready for approval at the highest international political level had finally been established.

\subsection{Adoption (2009-2010)}

This phase encompasses the 15th and 16th conferences of the parties to the climate convention in Copenhagen (2009) and Cancun (2010), in which the $2{ }^{\circ} \mathrm{C}$ target was recognised by a majority of countries (Decision 2/CP.15, UNFCCC 2009) and later formally agreed upon (Decision 1/CP.16, UNFCCC 2010). At the Copenhagen Conference, the target discussion had a favourable start. In the opening ceremony, a high number of influential countries $^{3}$ explicitly declared their support for an agreement that would include it. The target was formalised on the final day with the support of 141 countries. Moreover, the accord also suggested the consideration of a more ambitious target of $1.5{ }^{\circ} \mathrm{C}$ for the future.

This snapshot might signify a diplomatic success, but for the target itself it was instead a "tragic triumph" (Schellnhuber 2010: 229), as problems and instabilities had emerged

\footnotetext{
${ }^{3}$ Notably, Australia for the Umbrella Group (formed by Australia, New Zealand, Iceland, Russian Federation, Japan, Norway, Ukraine, Canada and the USA), Switzerland for the Environmental Integrity Group (formed by Mexico, Republic of Korea and Switzerland), Sweden for the EU (formed by 27 countries).
} 
before and during the conference. In the conference preparation, the two Ad Hoc Working Groups under the climate convention met five times, but no progress was made in terms of agreements (Bodansky 2011; Dimitrov 2010). Negotiations in Copenhagen were thus slow and the impossibility of making the $2{ }^{\circ} \mathrm{C}$ target obligatory was confirmed. At the same time, no global emissions reduction was specified, nor was a timeline defined, depriving the target of both a specific context and instruments for its concrete fulfilment. Some scholars, including Christoff (2010), Hulme (2010) and Bodansky (2011), attribute the lack of such a solution to the difficulties in offsetting differences among contracting parties. In particular, the USA and China remained uncooperative with the EU, while other countries remained substantially stuck in their positions (Barresi 2011; Hare et al. 2010).

The EU made a great effort to make the Copenhagen Conference a turning point in climate governance, while extending its own vision of $2{ }^{\circ} \mathrm{C}$ target as an accepted global climate system boundary. As previously discussed, the EU remained the main force behind the $2{ }^{\circ} \mathrm{C}$ target, using scientific and diplomatic efforts to extend its acceptance (Gippner 2014). In this way, it "succeeded in getting all relevant partners in the negotiationsincluding even China and the USA - to commit to the two-degree target" (Geden 2010: 2). Nonetheless, though Europe entered the negotiations with a firm idea of the target (Haug and Berkhout 2010), it was unable to shape the course of events with the USA refusing legally binding accords (Hare et al. 2010) which could challenge its wealth and economic structure. At the same time, China, Brazil, South Africa and many other developing countries remained focused on economic growth (Christoff 2010). Small Island Developing States, however, called for a target of no more than a $1.5^{\circ} \mathrm{C}$ increase in global temperature, supported by other countries that are particularly vulnerable to climate change. Competing interests, however, blocked a shared understanding on specific political solutions and coordinated measures to comply with the target.

After the framing and consolidation and diffusion phases, the debate on the target opened up at the UN. Having not been discussed in depth by international policymakers, the endorsements of the target-particularly in the consolidation and diffusion phase up to the opening statements of the Copenhagen Conference-collided with diverging interests and worldviews. In short, the target was thriving with no debate, but was weakened once brought to a global arena.

This result can be attributed to the concentration of high-level decision-makers-almost 120 state leaders-attending the final segment of the Copenhagen Conference (Dimitrov 2010) and by high public expectations and extensive media coverage (Boykoff 2011). ${ }^{4}$ Yet without a genuine overall consensus, a political accord of merely twelve paragraphs was reached, but only noted rather than adopted (Christoff 2010; Eckersley 2012). The direct involvement of heads of state and government, however, was particularly relevant for the $2{ }^{\circ} \mathrm{C}$ target, as the function and nature of the target radically changed. The Copenhagen accord transformed the target into a last resort commitment since the digit was the only quantitative element which proved consensual, as long as no measures or prescriptions were attached to it.

While compromises and mediations are common in international relations as well as in target setting (Turnhout et al. 2007), there was something more in this case. With the impending need for success and the public expectations for a tipping point after Kyoto, the best possible result was a target coated in vagueness, purposely formulated with constructed ambiguity and in sufficiently generic terms that it could be widely agreed upon by everybody. This gave form-rather than substance-to the $2{ }^{\circ} \mathrm{C}$ target, but gave no

${ }^{4}$ In particular, see the diagrams on pages $25-7,38,90$ and 110. 
indications for how it would be operationalised and implemented, as also confirmed by the conference of parties in Cancun that formally accepted the content of the Copenhagen Accord (Sepibus and Holzer 2014).

In sum, this phase, in which the target was approved at the highest political level, is marked by the reduced influence of Europe, the emergence of new political powers and the opening up of the debate over the consequences of the target. The presence of political leaders in Copenhagen was decisive for the outcome of negotiations. This favoured a target which was symbolic but nonetheless proved to be resilient. It survived to become an interpretation of article 2 of the 1992 climate convention, i.e. the objective of "stabilization of greenhouse gas concentrations in the atmosphere at a level that would prevent dangerous anthropogenic interference with the climate system" (UNFCCC 1992). The target thus succeeded in making an important step towards this common goal, yet political circumstances were not favourable for defining concrete actions.

\subsection{Disembeddedness (2011-2015)}

The conferences of Copenhagen and Cancun inscribed the $2{ }^{\circ} \mathrm{C}$ target on the international agenda. The conferences of the parties that followed-in Durban (2011), Doha (2012), Warsaw (2013) and Lima (2014)_revived international negotiations. However, in terms of the $2{ }^{\circ} \mathrm{C}$ target specifically, they did not lead to more ambitious policy responses (Blok et al. 2012), nor did they provide any substantial addition to the $2{ }^{\circ} \mathrm{C}$ target in terms of fulfilment (Bodansky and Diringer 2014; Pandey 2014). While these conferences marked some important innovation and advancement towards the global climate agreement expected to be reached by 2015 in Paris, the negotiating parties were still unable to define a common climate agenda, despite the agreement they reached with the Bali Action Plan ${ }^{5}$ in 2007. As such, the $2{ }^{\circ} \mathrm{C}$ target evolved into a stable and solid element but without a mobilising role at a more general level. This new phase was marked by a lack of specifications to make the $2{ }^{\circ} \mathrm{C}$ target more effective and by the inability to compel near-term political action (Lenton 2011a). Moreover, the target continued to fulfil a symbolic and declarative function, but did not offer political guidance for problem-solving (Geden 2013).

Reflecting on these processes, we characterise this phase as disembedded. Borrowing from the neologism "disembedded" coined by Polany (1944) as opposite to the adjective embedded, ${ }^{6}$ we argue that, after Copenhagen, the $2{ }^{\circ} \mathrm{C}$ had become a disembedded object. Officially, it is a global target. However, there is no established method for its successful implementation, and it is politically inert and unable to effectively limit the temperature increase.

The fact that the $2{ }^{\circ} \mathrm{C}$ is a disembedded object is indirectly confirmed by some academic and political positions that invoke the revision, reinterpretation, replacement or removal of the target from the international climate regime (Geden and Beck 2014; Jordan et al. 2013; Knopf et al. 2012; New et al. 2011). These positions evidence how the target, in its current

\footnotetext{
5 "A shared vision for long-term cooperative action, including a long-term global goal for emission reductions, to achieve the ultimate objective of the Convention" (Decision 1/CP.13 in FCCC/CP/2007/6/ Add.1).

6 The term disembedded, is used here neutrally, because of its lexical meaning. There is no reference to Polany's work, nor to other usages of the term in domains like economics, psychology, pedagogy, sociology. Here a "disembedded object" can be thought of as opposite to a "boundary object" (Star and Griesemer 1989).
} 
state, needs stronger interlinkages, renewed commitments and a more robust entrenchment in international environmental governance in order to be purposefully achieved.

In our view, the disembedded characterisation can be explained from three points of view: science and policy, domestic governance and international governance. In terms of science and policy, temperature is an ideal concept to connect scientists, policymakers and the general public. The $2{ }^{\circ} \mathrm{C}$ target is a global value for all, but temperature is a local variable that fluctuates significantly (Thornton et al. 2014). A temperature increase implies different risks and impacts at the local level that need to be aggregated and considered globally (Knutti et al. 2016). Moreover, a global mean temperature change is just one metric to reach a climate stabilisation goal. Emissions, cumulative concentration and radiative forces are metrics more related to human activities (Knopf et al. 2012) and need to be strongly combined to the $2{ }^{\circ} \mathrm{C}$ target to increase effectiveness and consistency of policy deliberations. Finally, temperature is both a cause and a consequence of environmental change and, because of the functional interdependence of natural sub-systems, it is connected to many transformative processes in the earth system (Biermann 2014). In the current configuration, the $2{ }^{\circ} \mathrm{C}$ target has no link to other critical thresholds in the earth system, such as country-level or local sub-targets (Philibert and Pershing 2001) or planetary limits (Rockström et al. 2009).

In terms of national policies, the absence of a coordinated agenda for implementing the $2{ }^{\circ} \mathrm{C}$ target and the lack of connected mitigation programmes inevitably disaggregates countries' actions making the global effort to stay within the $2{ }^{\circ} \mathrm{C}$ limit inconsistent (Raupach et al. 2014). Countries have now independently determined their climate mitigation goals - and possibly their adaptation plans-and presented their pledges that are now called, after the Warsaw Conference, Intended Nationally Determined Contributions (Decision 1/CP.19, UNFCCC 2013). Apart from the fact that the current aggregated contributions are most likely not sufficient to stay within the $2{ }^{\circ} \mathrm{C}$ temperature increase (Roelfsema et al. 2014; CAT 2015), the accounting mechanisms and the procedures for measurement, reporting and verification remain central in the negotiations. Nonetheless, they need substantial upgrading in accountability and transparency to promote trust among parties and to support a virtuous cycle of improvement (Dagnet et al. 2014).

The common goal defined by the target remains expressed in global terms but is difficult to operationalise globally and fine-tune locally because of different national capacities and priorities. In addition, in the current framing of the $2{ }^{\circ} \mathrm{C}$ target, the involvement of civil society is still limited, while transition and transformational change are hardly taken into account (Wise et al. 2012; Park et al. 2012). In fact, even if commendable initiatives have been launched (Blok et al. 2012) and voluntary arrangements with great potential like the International Cooperative Initiatives have been acknowledged by the Durban Platform for Enhanced Action (Widerberg and Pattberg 2014), these projects are still not representative of a true engagement of society as a whole to reach the target globally. Furthermore, the range of stakeholders involved in policy spaces remains marginal (Sepibus and Holzer 2014).

In terms of international governance, the $2{ }^{\circ} \mathrm{C}$ target poses problems of coordination among institutions. The role of international organisations is unclear, nor which would or could be in a position of leadership to stimulate nations to comply with the $2{ }^{\circ} \mathrm{C}$ limit. In an extremely fragmented global environmental governance setting (Biermann et al. 2009) with organisations having different mandates, approaches and structures, the $2{ }^{\circ} \mathrm{C}$ target proves difficult to be governed in a global architecture that does not clarify roles and functions for achieving it. In this context, detailed sub-targets related to the $2{ }^{\circ} \mathrm{C}$ and mandatory commitments prove to be politically infeasible. Instead, national voluntary 
contributions to stay within the target rely more on countries' individual reputation; they might weaken international institutions in their central role to guide and pursue collectively global goals. Concurrently, the identification of national contributions and the absence of an operational accounting system open the door to ambiguity and uncertainty. These can be attractive for countries that are unsure about adopting hard targets.

In sum, the $2{ }^{\circ} \mathrm{C}$ target evolved into a powerful and evocative reference for climate policy, but it remains incapable of promoting effective coordination among relevant actors. A global mean temperature seems to be a too vague attribution to make the target a focal point for policy intervention across multiple levels. As a consequence, the $2{ }^{\circ} \mathrm{C}$ target became a disembedded object, too weak and isolated to give strength and direction to coordinated actions in climate governance.

\section{The Paris agreement}

A major development-the impact of which is still difficult to evaluate-is the Paris Agreement reached in December 2015 by the conference of the parties to the climate convention. This Agreement stipulates to keep global temperature levels "well below $2{ }^{\circ} \mathrm{C}$ ", along with the further intention of "pursuing efforts to limit the temperature increase to $1.5^{\circ} \mathrm{C}$ " (UNFCCC 2015: 2). The additional line referring to the $1.5^{\circ} \mathrm{C}$ does not fundamentally change the overall target from $2{ }^{\circ} \mathrm{C}$, however. The notion of "well below $2{ }^{\circ} \mathrm{C}$ " does not indicate a precise level but reflects a further aspiration that emphasises the urgency of even stronger efforts in the coming years. As indicated in the Paris Agreement, in 2018 the Intergovernmental Panel on Climate Change will produce a special report on the $1.5^{\circ} \mathrm{C}$, but the current gap between aggregated countries pledges and the objective to stay within the $2{ }^{\circ} \mathrm{C}$ limit is significant, as also recognised in Paris. The $2{ }^{\circ} \mathrm{C}$ target thus continues to be the reference value in climate governance for the time being.

However, the Intended Nationally Determined Contributions will continue guiding country efforts on a self-determined basis. No coordinating mechanism or burden-sharing agreement is envisaged. There is also no binding requirement to implement existing pledges, nor to review or upgrade them, respectively, before 2020 and 2025. Starting in 2023, countries will re-evaluate their commitments every 5 years, with the option to strengthen their ambition level.

Furthermore, the 2015 Agreement notes the link between the temperature target and the global peaking of greenhouse gas emissions. This has to be reached "as soon as possible", with the aim of achieving "a balance between anthropogenic emissions by sources and removals by sinks of greenhouse gases in the second half of this century" (UNFCCC 2015: 21). This represents a step forward, even though the text does not specify a precise date for peaking and does not employ terms like climate or emissions neutrality for which some environmentalists had pushed. Overall, the Paris Agreement spells out robust global ambitions and proposes a mobilising vision for the future. Nonetheless, strict deadlines and commitments are absent from the agreement.

In terms of the $2{ }^{\circ} \mathrm{C}$ target, besides the major advancements in negotiations, the target remains a disembedded object in global environmental governance, as the main reasons for this condition endure. These are the lack of interlinkages with other relevant targets in the environmental and human domains; the lack of fine-tuning of the $2{ }^{\circ} \mathrm{C}$ target at different scales of governance and with the enlargement of the stakeholders involved; and the lack 
of adjustments in the institutional architecture combined with a robust monitoring and reporting system on the achievements. Even so, after Paris, many changes seem to be possible and achievable. Countries, together with the newly established Ad Hoc Working Group on the Paris Agreement and the Paris Committee on capacity-building, as well as with the two permanent subsidiary bodies ${ }^{7}$ established by the climate convention, have great potential to write a new phase of the $2{ }^{\circ} \mathrm{C}$ target.

\section{The way forward}

In the vein of the renewed interest on the $2{ }^{\circ} \mathrm{C}$ target and of the clear signal sent by the Paris Agreement to the international community, we discuss the way forward with regard to overcoming the weaknesses of the target that we summarised with the term disembeddedness. In order to address this challenge, we consider the approach proposed by Young et al. (2014) for the sustainable development goals. We believe this approach is equally suitable for the $2{ }^{\circ} \mathrm{C}$ target and useful for creating a consistent and effective framework to implement the target within an earth system governance perspective.

Young et al. (2014) envisage a multi-layered approach to achieve the sustainable development goals encompassing four tiers: (1) global goals that safeguard the human needs and earth life support systems; (2) individual goals and targets framed in such a way that they can serve as focal points for a wide range of stakeholders; (3) targets framed in global terms but-where possible and relevant-tailored at regional, national, local or corporate/organisational levels; (4) to define indicators and promote monitoring capabilities with the capacity to track change and report on progress.

This scheme, if applied to the $2{ }^{\circ} \mathrm{C}$ target, would have several implications. First, it would frame the temperature target within a wide system of other global goals for the sustainability of socio-ecological systems, such as the SDGs. This would better relate the target to anthropogenic drivers, earth transformation indicators, as well as environmental and human development targets, which all affect and are affected by temperature increases. In fact, "in the interlinked social and ecological systems of planet earth, nothing remains independent, and complexities and interconnections abound" (Biermann 2012: 7). Policymakers need access to a wider range of planetary indications to understand the full range of consequences of climate change (Briggs et al. 2015). Therefore, a systemic and comprehensive framework of interlinked targets and indicators, such as the SDGs, if shared and applied universally, would make the $2{ }^{\circ} \mathrm{C}$ target more meaningful and coherent with the operational context in which it should be accomplished. The approach by Young and colleagues could for instance favour iterative sets of science-policy dialogues within and between countries, as also proposed by Gupta and van Asselt (2006). This work suggests focusing on indicators of dangerous climate impacts, short-listing and grouping these indicators in a way to identify threshold levels of unacceptable impacts. As a consequence, the $2{ }^{\circ} \mathrm{C}$ target could be linked to these indicators and help define suitable countermeasures.

Second, the multi-layered approach would allow considering horizontal and vertical interactions while bridging levels of governance from global to local (Biermann and Pattberg 2012; Gupta et al. 2007). The explicit entrenchment of global commitments with national or sub-national priorities and actions would also foster knowledge production and

7 The two permanent subsidiary bodies are the Subsidiary Body for Scientific and Technological Advice and the Subsidiary Body for Implementation. 
transfer, while easing the identification of new policy options. This can define a strategy that integrates best available science, policy needs and "policy goals that reflect what policymakers actually control—and thus what they can manage" (Briggs et al. 2015: 969). In this way, coordination and convergence of measures might increase. The more coherent governance system that might derive from better coordination should facilitate achieving the $2{ }^{\circ} \mathrm{C}$ more efficiently on the basis of the capabilities of each country. At the same time, this approach would foster participation and support as the target becomes a focal point for multiple and interacting actors, network and institutions. Governments, international organisations, civil society, the private sector and individuals would be collectively involved in actions for staying within the $2{ }^{\circ} \mathrm{C}$ boundary.

Third, the approach can be employed to consistently adjust and enforce the global governance architecture in a way that defines comprehensive international programmes, institutional arrangements and practical commitments to comply with the $2{ }^{\circ} \mathrm{C}$ target. This requires the clarification of roles and mandates of international institutions. In these terms, the scheme would bridge the gap among sectoral silos by formulating the temperature target within crosscutting programmes and promoting a better articulation and integration in global governance. To complement and enforce these achievements, it is necessary to devise effective and universally applied procedures to track progress and provide indications for corrections or prescriptions to act in accordance with the $2{ }^{\circ} \mathrm{C}$ target.

The approach by Young and colleagues (2014) is inherently political as it requires the approval by policymakers. However, in such a scheme, the contentious issue of uncertainty does not disappear. Uncertainties are integral to human knowledge (Gramelsberger and Feichter 2011) and inextricable to complex systems. Staying within the $2{ }^{\circ} \mathrm{C}$ target asks for an unprecedented common vision combined with a proactive attitude to overcome

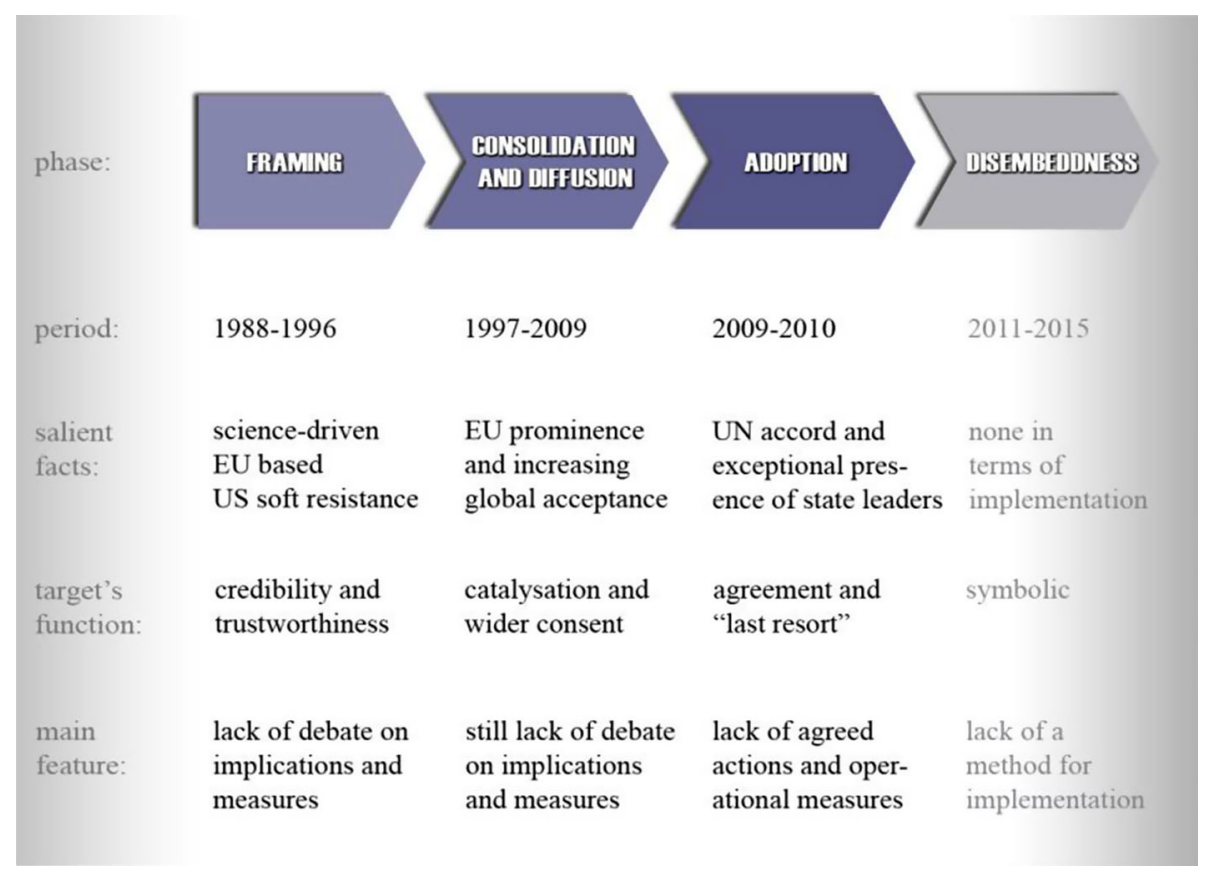

Fig. 1 The $2{ }^{\circ} \mathrm{C}$ target's phases 
contingency and vested interests. If so, a scheme like the one described can help frame the $2{ }^{\circ} \mathrm{C}$ target in how it becomes an earth system governance target. This would be a critical node to address multiple issues and an operational element to steer institutions at local and global levels towards mitigating and adapting to earth system transformations. A target so conceived can become a linchpin in global environmental governance, which coherently connects significant targets, fosters incisive measures and promotes coordination among different actors.

\section{Conclusions}

The reconstructed history of the $2{ }^{\circ} \mathrm{C}$ target presented in this paper has highlighted key features characterising its political dynamic (summarised in Fig. 1).

In the early phase, the target was science-driven and EU-based, that is, promoted by a group of European countries with soft resistance by the USA. The prominence of Europe persisted in the following phase, gaining, since 2005, the support of a larger number of countries, through a path-dependency of events that consolidated the target in the international arena. The adoption at the highest international level occurred at the Copenhagen Conference of the parties in 2009.

During the various phases the target confirmed the complex dynamics that characterised the target construction and stipulation with the involvement of several actors and institutions (Mitchell 2003; Turnhout et al. 2007; Lester and Neuhoff 2009; Sarewitz and Pielke 2007). The boundary object concept (Star 2010; Star and Griesemer 1989) helped to explore the different functions and contexts in which the target served policy. In the first phase, the target was a credible element in the science-policy interface, then turned to be a catalytic factor around which to build consent, to finally become a last resort element in the Copenhagen accord to ensure an outcome from the conference. Among governments and international decision-makers, a thorough political debate on engaging effectively with the target was absent during the first two phases; when this debate finally emerged in Copenhagen, it became evident that it was impossible to agree on the far-reaching commitments to stay within the limit. The new agreement in Paris 2015 might represent a watershed in climate negotiations, but perhaps now it is too soon to tell.

The reductio ad unum, reducing a complex issue to a single element-specifically, having a single-figure target for climate-was produced by events and circumstances. As every simplification, it brought ease in acceptance and difficulties in fulfilment. The selection of an absolute target with no articulation of its concrete implementation and a lack of shared global and local actions attached to it has transformed the $2{ }^{\circ} \mathrm{C}$ target from a boundary object to a disembedded object. Yet, this condition can be changed opting for a more complex, adaptive approach as the one by Young and colleagues (2014). For this, a true engagement by states, international organisations, civil society and the business community is needed to make the $2{ }^{\circ} \mathrm{C}$ more tangible and practical, possibly within a conceptual framework that facilitates real and global commitments. If this happens, the $2{ }^{\circ} \mathrm{C}$ target can become a fully fledged global environmental governance target and a powerful example of governing by targets.

Acknowledgement We are grateful to the three anonymous reviewers whose contribution highly improved the content of our manuscript. In this regard, we would also like to thank Jon Marco Church, Courtney Vegelin and Salvatore Aricò. Furthermore, we are grateful to Michael Oppenheimer and the many interviewees for their kindness and availability. A special thank you goes to Pier Vellinga for his help and 
support. Besides our gratitude to all these scholars, all opinions and errors are ours alone. Finally, we wish to thank Eleftheria Vasileiadou and Arthur Petersen for their collaboration in the earlier stages of this research. Eleftheria prematurely died this year. With this paper, we would like to remember her dedication and generosity.

Open Access This article is distributed under the terms of the Creative Commons Attribution 4.0 International License (http://creativecommons.org/licenses/by/4.0/), which permits unrestricted use, distribution, and reproduction in any medium, provided you give appropriate credit to the original author(s) and the source, provide a link to the Creative Commons license, and indicate if changes were made.

\section{References}

Asdal, K. (2008). Enacting things through numbers: Taking nature into account/ing. Geoforum, 39(1), $123-132$.

Barresi, P. (2011). US-China relations and the fate of the UN Framework Convention on Climate Change: Traditional conservatism as an ideological and cultural constraint on US participation in a successor to the Kyoto protocol on Chinese terms. Chinese Journal of International Law, 10, 609-649.

Barrett, S. (2003). Environment and statecraft: The strategy of environmental treaty-making. Oxford: Oxford University Press.

Bergh, G., \& Couturier, J. (2013). A rough guide to emerging consensus and divergence in post-2015 goal areas. London: Overseas Development Institute.

Biermann, F. (1997). "Common Concern of Humankind": The emergence of a new concept of International Environmental Law. Archiv des Völkerrechts, 34(4), 426-481.

Biermann, F. (2012). Planetary boundaries and earth system governance: Exploring the links. Ecological Economics, 81, 4-9.

Biermann, F. (2014). Earth system governance. World politics in the anthropocene. Cambridge, MA: MIT Press.

Biermann, F., \& Pattberg, P. (2012). Global environmental governance-conclusion. In F. Biermann \& P. Pattberg (Eds.), Global environmental governance reconsidered (pp. 265-280). Cambridge, MA: MIT Press.

Biermann, F., Pattberg, P., van Asselt, H., \& Zelli, F. (2009). The fragmentation of global governance architectures: A framework for analysis. Global Environmental Politics, 9(4), 14-40.

Blok, K., Höhne, N., van der Leun, K., \& Harrison, N. (2012). Bridging the greenhouse-gas emissions gap. Nature Climate Change, 2, 471-474.

Bodansky, D. (2010). The Copenhagen climate change conference: A post-mortem. American Journal of International Law, 104, 230-240.

Bodansky, D. (2011). A tale of two architectures: The once and future UN climate change regime. Arizona State Law Journal, 43, 697-712.

Bodansky, D., \& Diringer, E. (2014). Building flexibility and ambition into a 2015 climate agreement. Arlington, VA: Center for Climate and Energy Solutions.

Bowker, G. C., \& Star, S. L. (1996). How things (actor-net) work: Classification, magic and the ubiquity of standards. Philosophia, 25(3-4), 195-220.

Bowker, G. C., \& Star, S. L. (1999). Sorting things out: Classification and its consequences. Cambridge, MA: The MIT Press.

Boykoff, M. T. (2011). Who speaks for the climate? Making sense of media reporting on climate change. Cambridge: Cambridge University Press.

Boykoff, M. T., Frame, D., \& Randalls, S. (2010). Discursive stability meets climate instability: A critical exploration of the concept of 'climate stabilization' in contemporary climate policy. Global Environmental Change, 20(1), 53-64.

Briggs, S., Kennel, C. F., \& Victor, D. G. (2015). Planetary vital signs. Nature Climate Change, 5(11), 969-970.

Cash, D. W. (2000). Distributed assessment systems: An emerging paradigm of research, assessment and decision-making for environmental change. Discussion Paper 2000-2006. Cambridge, MA: Belfer Center for Science and International Affairs (BCSIA).

CAT-Climate Action Tracker (2015). $2.7^{\circ} \mathrm{C}$ is not enough-we can get lower. Climate Action Tracker Update. 8 Dec 2015. http://climateactiontracker.org/assets/publications/briefing_papers/CAT_Temp_ Update_COP21.pdf. Accessed 26 Jan 2015. 
Cavender-Bares, J., Jager, J., \& Ell, R. (2001). Developing a precautionary approach: Global environmental risk management in Germany. In W. C. Clark, J. Jäger, J. van Eijndhoven, \& N. Dickson (Eds.), Learning to manage global environmental risks: A comparative history of social responses to climate change, ozone depletion, and acid rain (Vol. 1, pp. 61-92). Cambridge, MA: MIT Press.

Christoff, P. (2010). Cold climate in Copenhagen: China and the United States at COP15. Environmental Politics, 19(4), 637-656.

Climate Group. (2008). Breaking the climate deadlock. A global deal for our low-carbon future. http://www. theclimategroup.org/_assets/files/Global-Deal-for-our-Low-Carbon-Futrue-Exec-Summ.pdf. Accessed 29 Oct 2015.

Cointe, B., Ravon, P. A., \& Guèrin, E. (2011). $2{ }^{\circ} \mathrm{C}$ : The history of a policy-science nexus. Working papers No. 19. Paris: IDDRI.

Commission of the European Communities (2005). Communication from the Commission to the Council, the European Parliament, the European Economic and Social Committee and the Committee of the Regions, Winning the Battle Against Global Climate Change. COM(2005) 35 final, 9 Feb 2005, Brussels, Belgium. http://eur-lex.europa.eu/legal-content/EN/TXT/PDF/?uri=CELEX:52005DC0035\& from=bg. Accessed 29 Oct 2015.

Council of the European Union (1996). 1939th Council Meeting, Luxembourg, 25 June 1996. http://europa. eu/rapid/press-release_PRES-96-188_en.htm?locale=en. Accessed 29 Oct 2015.

Council of the European Union. (2005). Presidency conclusions-Brussels, 22 and 23 March 2005-IV. Climate change, 7619/1/05 REV 1 CONCL 1, Brussels, Belgium. http://www.consilium.europa.eu/ uedocs/cms_data/docs/pressdata/en/ec/84335.pdf. Accessed 29 Oct 2015.

Dagnet, Y., Fei, T. , Elliott, C., \& Qiu, Y. (2014). Improving transparency and accountability in the post2020 climate regime: A fair way forward. Working Paper. Washington, DC: Agreement for Climate Transformation 2015 (ACT 2015).

Davis, K. E., Kingsbury, B., \& Merry, S. E. (2012). Indicators as a technology of global governance. Law and Society Review, 46(1), 71-104.

Death, C. (2011). Summit theatre: Exemplary governmentality and environmental diplomacy in Johannesburg and Copenhagen. Environmental Politics, 20(1), 1-19.

Dietrich, W. (1995). The challenge of selecting goals: Case studies regarding the use of critical levels. CSIA Discussion Paper 95-05. Cambridge, MA: Kennedy School of Government.

Dimitrov, R. S. (2010). Inside Copenhagen: The state of climate. Global Environmental Politics, 10(2), $18-24$.

Eckersley, R. (2012). Moving forward in the climate negotiations: Multilateralism or minilateralism? Global Environmental Politics, 12(2), 24-42.

Finnemore, M., \& Sikkink, K. (1998). International norm dynamics and political change. International Organization, 52(4), 887-917.

G8. (2003). Science and technology for sustainable development. A G8 action plan. Resource document. G8 France. http://www.g8.utoronto.ca/summit/2003evian/sustainable_development_en.html. Accessed 29 Oct 2015.

G8. (2005). Gleneagles communiqué. Resource document. G8 Information centre. www.g8.utoronto.ca/ summit/2005gleneagles/communique.pdf. Accessed 29 Oct 2015.

G8. (2009). G8 leaders declaration: Responsible leadership for a sustainable future, 8.-10.7.09. Resource document. G8 Italy. http://www.g8italia2009.it/static/G8_Allegato/G8_Declaration_08_07_09_final,0. pdf. Accessed 29 Oct 2015.

Geden, O. (2010). What comes after the two-degree target? The EU's climate policy should advocate for flexible benchmarks. SWP Comments. Berlin: German Institute for International and Security Affairs.

Geden, O. (2013). Modifying the 2C target: Climate policy objectives in the contested terrain of scientific policy advice, political preferences, and rising emissions. SWP Research Paper Berlin: German Institute for International and Security Affairs.

Geden, O., \& Beck, S. (2014). Renegotiating the global climate stabilization target. Nature Climate Change, 4, 747-748.

Gippner, O. (2014). The $2{ }^{\circ} \mathrm{C}$ target: A European norm enters the international stage-following the process to adoption in China. International Environmental Agreements, 15(1), 1-17.

Gramelsberger, G., \& Feichter, J. (2011). Introduction to the Volume. In G. Gramelsberger \& J. Feichter (Eds.), Climate change and policy: The calculability of climate change and the challenge of uncertainty (pp. 1-8). Berlin: Springer.

Grubb, M. (1990). The greenhouse effect: Negotiating targets, vol. 66, no. 1. International Affairs (Royal Institute of International Affairs 1944) pp. 67-89.

Grundmann, R. (2006). Ozone and climate scientific consensus and leadership. Science Technology Human Values, 31, 73-101. 
Gupta, J., \& van Asselt, H. (2006). Helping operationalise article 2: A transdisciplinary methodological tool for evaluating when climate change is dangerous. Global Environmental Change, 16, 83-94.

Gupta, J., Van Der Leeuw, K., \& De Moel, H. (2007). Climate change: A 'glocal' problem requiring 'glocal' action. Environmental Sciences, 4(3), 139-148.

Haas, P. M., Keohane, R. O., \& Levy, M. A. (Eds.). (1993). Institutions for the earth: Sources of effective international environmental protection. Cambridge, MA: MIT Press.

Hák, T., Moldan, B., \& Dahl, A. L. (Eds.). (2007). Sustainability indicators. A scientific assessment. Washington, DC: Island Press.

Hare, W., Stockwell, C., Flachsland, C., \& Oberthür, S. (2010). The architecture of the global climate regime: A top-down perspective. Climate Policy, 10(6), 600-614.

Haug, C., \& Berkhout, F. (2010). Learning the hard way? European climate policy after Copenhagen. Environment: Science and Policy for Sustainable Development, 52(3), 20-27.

Höhne, N., \& den Elzen, M. (2013). The gap between the pledges and emissions needed for $2{ }^{\circ} \mathrm{C}$. In K. H. Olsen, J. Fenhann, \& S. Lütken (Eds.), Elements of a new climate agreement by 2015 (pp. 9-20). Roskilde: UNEP Ris $\emptyset$ Centre.

Hulme, M. (2010). Moving beyond climate change. Environment: Science and Policy for Sustainable Development, 52(3), 15-19.

Hunt, J., \& Shackley, S. (1999). Reconceiving science and policy: Academic, fiducial and bureaucratic knowledge. Minerva, 37(2), 141-164.

ICCT. (2005). Meeting the climate challenge, recommendations of the international climate change taskforce. Washington, D.C.: Institute for Public Policy Research, Center for American Progress, and Australia Institute.

International Scientific Steering Committee. (2005). avoiding dangerous climate change: International symposium on the stabilization of greenhouse gas concentrations. London: department for environment, food and rural affairs. http://eeg.tuwien.ac.at/eeg.tuwien.ac.at_pages/publications/pdf/NAK_ BOO_2006_01_summary.pdf. Accessed 29 Oct 2015.

Jaeger, C., \& Jaeger, J. (2010). Three views of two degrees. Climate Change Economics, 1(3), 145-166.

Jänicke, M., \& Jörgens, H. (Eds.). (2006). New approaches to environmental governance. In Environmental governance in global perspective. New approaches to ecological and political modernisation (pp. 167-209). Berlin: Freie Universität Berlin.

Jasanoff, S. (1990). The fifth branch, science advisers as policymakers. Cambridge, MA: Harvard University Press.

Jordan, A., \& Huitema, D. (2014). Innovations in climate policy: The politics of invention, diffusion, and evaluation. Environmental Politics, 23(5), 715-734.

Jordan, A., Rayner, T., Schroeder, H., Adger, N., Anderson, K., Bows, A., et al. (2013). Going beyond two degrees? The risks and opportunities of alternative options. Climate Policy, 13(6), 751-769.

Kanie, N., \& Biermann, F. (Eds.). (2017). Governance through Goals: New strategies for sustainable development. Cambridge, MA: MIT Press.

Knopf, B., Kowarsch, M., Flachsland, C., \& Edenhofer, O. (2012). The $2{ }^{\circ} \mathrm{C}$ target reconsidered. In O. Edenhofer, J. Wallacher, H. Lotze-Campen, M. Reder, B. Knopf, \& J. Müller (Eds.), Climate change, justice and sustainability: Linking climate and development policy (pp. 122-125). Dordrecht: Springer.

Knutti, R., Rogelj, J., Sedláček, J., \& Fischer, E. M. (2016). A scientific critique of the two-degree climate change target. Nature Geoscience, 9(1), 13-18.

Lenton, T. (2011a). Beyond $2{ }^{\circ} \mathrm{C}$ : Redefining dangerous climate change for physical systems. Wiley Interdisciplinary Reviews: Climate Change, 2, 451-461.

Lenton, T. (2011b). $2{ }^{\circ} \mathrm{C}$ or not $2{ }^{\circ} \mathrm{C}$ ? That is the climate question. Nature, $473,7$.

Lester, S., \& Neuhoff, K. (2009). Understanding the role of policy targets in National and International Governance. EPRG Working Paper 0909. Cambridge: University of Cambridge.

Mahony, M., \& Hulme, M. (2012). The colour of risk: an exploration of the IPCC's "burning embers" diagram. Spontaneous Generations: A Journal for the History and Philosophy of Science, 6(1), 75-89.

Manabe, S., \& Wetherald, R. T. (1967). Thermal equilibrium of the atmosphere with a given distribution of relative humidity. Journal of the Atmospheric Sciences, 24(3), 241-259.

MEF (2009). Major economies forum declaration of the leaders. The Major economies forum on energy and climate, 9.7.09. https://www.whitehouse.gov/the-press-office/declaration-leaders-major-economiesforum-energy-and-climate. Accessed 29 Oct 2015.

Metz, B. (2010). Controlling Climate change. Cambridge: Cambridge University Press.

Miller, C. A. (2005). New civic epistemologies of quantification: Making sense of indicators of local and global sustainability. Science, Technology and Human Values, 30(3), 403-432.

Mitchell, R. B. (2003). International environmental agreements: A survey of their features, formation, and effects. Annual Review of Environment and Resources, 28, 429-461. 
Mitchell, R. B., Clark, W. C., Cash, D. W., \& Dickson, N. M. (Eds.). (2006). Global environmental assessments: Information and influence. Cambridge, MA: MIT Press.

New, M., Liverman, D., Schroeder, H., \& Anderson, K. (2011). Four degrees and beyond: The potential for a global temperature increase of four degrees and its implications. Philosophical Transactions of the Royal Society of London A: Mathematical, Physical and Engineering Sciences, 369(1934), 6-19.

Oberthür, S., \& Ott, H. E. (Eds.). (2010). The Kyoto Protocol: International climate policy for the 21st century. Berlin: Springer.

Oppenheimer, M., \& Petsonk, A. (2005). Article 2 of the UNFCCC: Historical origins, recent interpretations. Climatic Change, 73, 195-226.

Pandey, C. L. (2014). The limits of climate change agreements: From past to present. International Journal of Climate Change Strategies and Management, 6(4), 376-390.

Park, S. E., Marshall, N. A., Jakku, E., Dowdd, A. M., Howden, S. M., Mendhamf, E., et al. (2012). Informing adaptation responses to climate change through theories of transformation. Global Environmental Change, 22, 115-126.

Peters, R. G., Covello, V. T., \& McCallum, D. B. (1997). The determinants of trust and credibility in environmental risk communication: An empirical study. Risk Analysis, 17(1), 43-54.

Pettenger, M. E. (2007). The Netherlands' climate change policy: Constructing themselves/constructing climate change. In M. E. Pettenger (Ed.), The social construction of climate change. Power, knowledge, norms, discours (pp. 51-73). Aldershot: Ashgate.

Philibert, C., \& Pershing, J. (2001). Considering the options: Climate targets for all countries. Climate Policy, 1, 211-227.

Pierson, P. (2000). Increasing returns, path dependence, and the study of politics. The American Political Science Review, 94(2), 251-267.

Polany, K. (1944). The great transformation, the political and economic origins of our time. Boston, MA: Beacon Press.

Porter, T. M. (1995). Trust in numbers. The Pursuit of objectivity in science and public life. Princeton, NJ: Princeton University Press.

Randalls, S. (2010). History of the $2{ }^{\circ} \mathrm{C}$ climate target. Wiley Interdisciplinary Reviews: Climate Change, 1 , 598-605.

Randalls, S. (2011). Optimal climate change: Economics and climate science policy histories (from heuristic to normative). Osiris, 26(1), 224-242.

Raupach, M. R., Davis, S. J., Peters, G. P., Andrew, R. M., Canadell, J. G., Ciais, P., et al. (2014). Sharing a quota on cumulative carbon emissions. Nature Climate Change, 4(10), 873-879.

Renn, O., \& Levine, D. (1991). Credibility and trust in risk communication. In R. E. Kasperson \& P. J. M. Stallen (Eds.), Communicating risks to the public: International perspectives (Vol. 4, pp. 175-217). Dordrecht: Springer.

Rijsberman, F., \& Swart, R. (Eds.). (1990). Targets and indicators of climate change: Report of working group ii of the advisory group on greenhouse gases. Stockholm: The Stockholm Environment Institute.

RIVM. (1988). Concern for tomorrow: A national environmental survey 1985-2010; RIVM Rapport 010198901. Bilthoven: Rijksinstituut voor Volksgezondheid en Milieu.

Rockström, J., Steffen, W., Noone, K., Persson, A., Chapin, S. F., Lambin, E. F., et al. (2009). Planetary boundaries: Exploring the safe operating space for humanity. Ecology and Society, 14, 32.

Roelfsema, M., den Elzen, M., Höhne, N., Hof, A. F., Braun, N., Fekete, H., et al. (2014). Are major economies on track to achieve their pledges for 2020? An assessment of domestic climate and energy policies. Energy Policy, 67, 781-796.

Rotmans, J. (1990). IMAGE. An integrated model to assess the greenhouse effect. Dordrecht: Kluwer Academic Publishers.

Sarewitz, D., \& Pielke, R. A. (2007). The neglected heart of science policy: Reconciling supply of and demand for science. Environmental Science and Policy, 10(1), 5-16.

Schellnhuber, H. J. (2010). Tragic triumph. Climatic Change, 100, 229-238.

Schellnhuber, H. J., Cramer, W., Nakicenovic, N., Wigley, T., \& Yone, G. (2006). Avoiding Dangerous climate change. Cambridge: Cambridge University Press.

Sepibus, J. D., \& Holzer, K. (2014). UNFCCC at a crossroads. Carbon and Climate Law Review, 1, 23-34.

Shaw, C. (2010). The dangerous limits of dangerous limits: Climate change and the precautionary principle. In B. Carter \& N. Charles (Eds.), Nature, society and environmental crisis (pp. 103-123). Oxford: Wiley.

Shaw, C. (2013). Choosing a dangerous limit for climate change: Public representations of the decision making process. Global Environmental Change, 23(2), 563-571.

Star, S. L. (2010). This is not a boundary object: Reflections on the origin of a concept. Science, Technology and Human Values, 35(5), 601-617. 
Star, S. L., \& Griesemer, J. R. (1989). Institutional ecology, translations' and boundary objects: Amateurs and professionals in Berkeley's Museum of Vertebrate Zoology, 1907-39. Social Studies of Science, 19(3), 387-420.

Swart, R. J., \& Vellinga, P. (1994). The 'ultimate objective' of the framework convention on climate change requires a new approach in climate change research. Climatic Change, 26, 343-349.

SWCC. (1990) Declaration of the second world climate conference. In Jager, J., \& Ferguson, H. L. (Eds.) (1991), Climate change: Science, impacts and policy-Proceedings of the second world climate conference. Cambridge: Cambridge University Press.

Thornton, P. K., Ericksen, P. J., Herrero, M., \& Challinor, A. J. (2014). Climate variability and vulnerability to climate change: A review. Global Change Biology, 20(11), 3313-3328.

Tol, R. S. J. (2007). Europe's long-term climate target: A critical evaluation. Energy Policy, 35, 424-432.

Torrance, W. E. F. (2006). Science or salience: Building an agenda for climate change. In R. B. Mitchell, W. C. Clark, D. W. Cash, \& N. M. Dickson (Eds.), Global environmental assessments. Information and influence. Cambridge, MA: MIT Press.

Turnhout, E., Hisschemöller, M., \& Eijsackers, H. (2007). Ecological indicators: Between the two fires of science and policy. Ecological Indicators, 7(2), 215-228.

Underdal, A. (2000). Science and politics: The anatomy of an uneasy partnership. In S. Andresen, T. Skodvin, A. Underdal, \& J. Wettestad (Eds.), Science and politics in international environmental regimes (pp. 1-21). Manchester: Manchester University Press.

UNEP. (2013). The emissions gap report 2013.

UNFCCC. (1992). The United Nations framework convention on climate change. 1992 FCCC/INFORMAL/ 84 GE.05-62220 (E) 200705.

UNFCCC. (2007). Report of the conference of the parties at its thirteenth session, held in Bali from 3 to 15 December 2007, Addendum, part two: Actions taken by the conference of the parties at its thirteenth session. FCCC/CP/2007/6/Add.1.

UNFCCC. (2009). Report of the conference of the parties on its fifteenth session, held in Copenhagen from 7 to 19 December 2009 Addendum part two: Action taken by the conference of the parties at its fifteenth session. FCCC/CP/2009/11/Add.1.

UNFCCC. (2009). Draft decision-/CP.15 proposal by the president Copenhagen Accord. FCCC/CP/2009/ L.7.

UNFCCC. (2010). The Cancun agreements: Outcome of the work of the Ad Hoc Working Group on Longterm Cooperative Action under the Convention. FCCC/CP/2010/7/Add.1.

UNFCCC. (2013). Further advancing the Durban platform. FCCC/CP/2013/10/Add.1.

UNFCCC. (2015). Adoption of the Paris agreement. Proposal by the president. Draft decision-/CP.21. FCCC/CP/2015/L.9/Rev.1.

van der Sluijs, J., van Eijndhoven, J., Shackley, S., \& Wynne, B. (1998). Anchoring devices in science for policy: The case of consensus around climate Sensitivity. Social Studies of Science, 28, 291-323.

van Eijndhoven, J., Dinkelman, G., van der Sluijs, J., Pleune, R., \& Worrell, C. (2001). Finding your place: A history of the management of global environmental risks in the Netherlands, Vol. 1. A comparative history of social responses to climate change, ozone depletion, and acid rain. In Social learning group. Learning to manage global environmental risks. 2. A functional analysis of social responses to climate change, ozone depletion, and acid rain. Vol. 2 (pp. 115-138). Cambridge, MA: MIT Press.

van Vliet, J., van den Berg, M., Schaeffer, M., van Vuuren, D. P., den Elzen, M., Hof, A. F., et al. (2012). Copenhagen Accord Pledges imply higher costs for staying below $2{ }^{\circ} \mathrm{C}$ warming. Climatic Change, $113,551-561$.

Vellinga, P., \& Swart, R. J. (1991). The greenhouse marathon: A proposal for a global strategy. Climatic Change, 18, 7-12.

Watson, R. T. (2005). Turning science into policy: Challenges and experiences from the science-policy interface. Philosophical Transactions of the Royal Society of London B: Biological Sciences, 360(1454), 471-477.

WBGU. (1995). Scenario for the derivation of global CO2 reduction targets and implementation strategies. Statement on the occasion of the first conference of the parties to the framework convention on climate change in Berlin. Berlin: Wissenschaftlicher Beirat der Bundesregierung Globale Umweltveränderungen, WBGU.

WBGU. (1996). World in transition: Ways towards global environmental solutions. Berlin: Wissenschaftlicher Beirat der Bundesregierung Globale Umweltveränderungen, WBGU.

WBGU. (2009). Special Report, Solving the climate dilemma: The budget approach. Berlin: Wissenschaftlicher Beirat der Bundesregierung Globale Umweltveränderungen, WBGU.

Whyte, K. P., \& Crease, R. P. (2010). Trust, expertise, and the philosophy of science. Synthese, 177, 411-425. 
Widerberg, O., \& Pattberg, P. (2014). International cooperative initiatives in global climate governance: Raising the ambition level or delegitimizing the UNFCCC? Global Policy, 6(1), 45-56.

Wise, R. M., Fazey, I., Stafford Smith, M., Park, S. E., Eakin, H. C., Archer Van Garderen, E. R. M., et al. (2012). Reconceptualising adaptation to climate change as part of pathways of change and response. Global Environmental Change, 28, 325-336.

WMO. (1988). Developing policies for responding to climatic change, A summary of the discussions and recommendations of the workshops held in Villach (28 September to 2 October 1987) and Bellagio (913 November 1987) under the Auspices of the Beijer Institute. Stockholm, World Climate Impact studies Program, World Meteorological Organization. WCIP-1 WMO/TD-No. 225.

Yamin, F. (2000). The role of the EU in climate negotiations. In J. Gupta \& M. Grubb (Eds.), Climate change and European leadership (pp. 47-66). Dordrecht: Springer.

Young, O. R., \& Levy, M. A. (1999). The effectiveness of international environmental regimes. In O. R. Young (Ed.), The effectiveness of international environmental regimes: Causal connections and behavioral mechanisms (pp. 1-32). Cambridge, MA: MIT Press.

Young, O., Underdal, A., Kanie, N., Andresen, S., Bernstein, S., \& Biermann, F., et al. (2014). Earth system challenges and a multi-layered approach for the sustainable development goals. Post2015/UNU-IAS Policy Brief \#1. Tokyo: United Nations Institute for Advanced Study of Sustainability. 